120 AT-TAWASSUTH: Jurnal Ekonomi Islam, Volume V No. 1

Januari - Juni 2020: 120 - 141

\title{
RISIKO KEUANGAN DAN PENGARUHNYA TERHADAP PROFITABILITAS BANK SYARIAH DI INDONESIA
}

\author{
Pani Akhiruddin Siregar \\ STAI Panca Budi Perdagangan \\ panisiregar81@gmail.com
}

\begin{abstract}
Research aims to test financial risk and influence on the profitability of Sharia Bank in Indonesia. Financial risk indicators include CAR, NPF, BOPO, FDR and ROE. Profitability indicators of Sharia Banks in Indonesia are ROA. The research method uses a quantitative approach with multiple linear regression analysis techniques. Data used secondary data in the form of a monthly data From The Financial Report of Sharia Commercial Bank and Sharia Business Unit published by Sharia Banking Directorate, Bank Indonesia and the Bank Licensing and Banking Information Department, Indonesia Financial Services Authority from January 2006 to January 2018. Research results: (1)The result of the model estimate shows its $R^{2}$ value of 0,614 representing the value of coefficient of determination. This means that $61,40 \%$ of the variable variations of the ROA are capable of being described by independent variable in this model. The remaining $38,60 \%$ is explained by other reasons that do'nt fit into the model; (2)A regression model on the independent variable simultaneously affects the dependent variable, so that the independent variable regression model can be used to predict the dependent variable; and (3)CAR, NPF and FDR are significantly influence on ROA. BOPO and ROE influential on ROA. But, it's not significant.
\end{abstract}

Keywords: CAR, NPF, BOPO, FDR, ROE, ROA

\begin{abstract}
Abstrak
Penelitian bertujuan untuk menguji risiko keuangan dan pengaruhnya terhadap profitabilitas Bank Syariah di Indonesia. Indikator risiko keuangan meliputi CAR, NPF, BOPO, FDR dan ROE. Adapun indikator profitabilitas Bank Syariah di Indonesia adalah ROA. Metode penelitian menggunakan pendekatan kuantitatif dengan teknik analisis regresi linier berganda. Data yang digunakan data sekunder bulanan dari Laporan Keuangan Bank Umum Syariah dan Unit Usaha Syariah yang dipublikasikan Direktorat Perbankan Syariah, Bank Indonesia serta Departemen Perizinan dan Informasi Perbankan, Otoritas Jasa Keuangan Indonesia periode Januari 2006 hingga Januari 2018. Hasil penelitian: (1)Model estimasi menunjukkan nilai $\mathrm{R}^{2}$ sebesar 0,614 yang mewakili nilai koefisien determinasi. Hal ini bermakna $61,40 \%$ dari variasi variabel ROA mampu dijelaskan oleh variabel bebas dalam model ini. Sedangkan sisanya sebesar 38,60\% dijelaskan oleh sebabsebab lain yang tidak masuk dalam model; (2)Model regresi pada variabel bebas secara simultan mempengaruhi variabel terikat, sehingga model regresi variabel bebas bisa dipakai untuk memprediksi variabel terikat; dan (3)CAR, NPF dan
\end{abstract}


Pani Akhiruddin: Risiko Keuangan Dan Pengaruhnya $\mid 121$

FDR berpengaruh dan signifikan terhadap ROA. BOPO dan ROE berpengaruh terhadap ROA. Namun, tidak signifikan.

Kata kunci: CAR, NPF, BOPO, FDR, ROE, ROA

\section{Pendahuluan}

Bank $^{1}$ dalam kegiatan operasionalnya sebagai sebuah lembaga keuangan yang berfungsi sebagai intermediasi antara pihak surplus dana dengan pihak defisit dana selalu penuh dengan risiko. Bank menarik dana dari masyarakat (surplus dana) dengan menawarkan berbagai jenis produk simpanan, seperti giro, tabungan dan deposito yang hampir kesemuanya berjangka pendek (kurang dari setahun). Sementara di sisi lain, bank menyalurkan dana kepada masyarakat (defisit dana) dalam bentuk pinjaman maupun pembiayaan yang hampir kesemuanya berjangka panjang (lebih dari setahun) dan tidak dapat dilikuidasi dalam waktu singkat. Ketidakcocokan waktu inilah yang menjadi sumber utama risiko pada perbankan. Bank sebesar dan semapan apa pun akan jatuh dalam waktu singkat sekiranya semua nasabah (pihak surplus dana) dalam waktu yang bersamaan menarik dananya (bank rush) sementara berbagai pinjaman atau pembiayaan yang disalurkan ke nasabah (pihak defisit dana) tidak dapat segera dicairkan. Sebab, risiko yang melekat pada lembaga keuangan tidak dapat dihilangkan dan tentunya akan selalu membayangi kegiatan operasional bank setiap saat. ${ }^{2}$

Setiap bank baik konvensional maupun syariah diwajibkan untuk menyajikan dan mempublikasikan laporan keuangan yang salah satu tujuannya agar masyarakat umum dapat melihat kinerja bank yang bersangkutan. Hal ini penting karena tingkat kepercayaan masyarakat terhadap suatu bank untuk menyimpan dananya dipengaruhi kinerja bank yang bersangkutan. Hal ini pun dapat dilihat dari posisi keuangan, melalui neraca dan perhitungan laba/rugi dengan cara membandingkannya dengan neraca atau perhitungan laba/rugi bank lain atau dengan membandingkan neraca bank tersebut, untuk waktu atau tahun yang berbeda. $^{3}$ Berdasarkan laporan keuangan inilah dapat dihitung sejumlah rasio keuangan yang lazim dijadikan dasar dari penilaian kinerja bank. Rasio keuangan 
dapat digunakan untuk mengukur kinerja karena rasio-rasio tersebut pun terbukti berperan penting dalam evaluasi kinerja keuangan serta dapat digunakan untuk memprediksi kelangsungan usaha baik yang sehat maupun yang tidak sehat. Penilaian kinerja bank dilakukan dengan menganalisis rasio keuangan.

Analisis rasio keuangan adalah indeks yang menghubungkan dua angka akuntansi dan diperoleh dengan membagi satu angka dengan angka lainnya. Rasio ini digunakan untuk mengevaluasi kondisi keuangan dan kinerja bank ${ }^{4}$ pun risiko keuangan karena penting untuk memastikan risiko keuangan diidentifikasi dan dikelola dengan tepat. ${ }^{5}$ Dalam penilaian tingkat kesehatan bank ${ }^{6}$, Bank Syariah memasukkan risiko yang melekat pada aktivitasnya yang merupakan bagian dari proses penilaian manajemen risiko. $^{7}$ Manajemen risiko dibutuhkan untuk mengidentifikasi, mengukur dan mengendalikan berbagai macam risiko, ${ }^{8}$ sehingga bank tetap melakukan pemantauan terhadap risiko dan pengelolaannya. ${ }^{9}$ Hal ini bermakna perbankan merupakan kegiatan bisnis yang penuh risiko di samping menjanjikan keuntungan yang besar. Dikatakan bisnis penuh risiko karena aktivitas bank sebagian besar mengandalkan dana titipan masyarakat baik dalam bentuk tabungan, giro maupun deposito, ${ }^{10}$ sehingga diharapkan naiknya profitabilitas.

Bank Indonesia lebih mengutamakan nilai profitabilitas suatu bank yang diukur dengan aset yang dananya sebagian berasal dari dana simpanan masyarakat, sehingga Return on Assets (ROA) mewakili dalam mengukur tingkat profitabilitas perbankan. ${ }^{11}$ Dengan demikian, dalam memahami risiko terlebih risiko keuangan yang berpengaruh terhadap profitabilitas Bank Syariah, Bank Syariah diharuskan untuk memantau situasi perekonomian secara mikroekonomi dan makroekonomi agar keputusan bisnis yang diambil dapat melindungi kepentingan berbagai pihak utamanya pihak penyimpan dana dan pihak pengguna dana yang berdampak Bank Syariah dapat mengkonversi risiko keuangan menjadi peluang bisnis yang menguntungkan. Berdasarkan uraian, tujuan dari penelitian ini adalah untuk menguji risiko keuangan dan pengaruhnya terhadap profitabilitas Bank Syariah di Indonesia. 
Pani Akhiruddin: Risiko Keuangan Dan Pengaruhnya $\mid 123$

\section{Kajian Literatur \\ Bank Syariah}

Undang-Undang Nomor 21 Tahun 2008 Tentang Perbankan Syariah menyatakan "Bank Syariah adalah bank yang menjalankan kegiatan usahanya berdasarkan prinsip syariah dan menurut jenisnya terdiri atas Bank Umum Syariah dan Bank Pembiayaan Rakyat Syariah. Sedangkan yang dimaksud dengan perbankan syariah adalah segala sesuatu yang menyangkut tentang Bank Syariah dan Unit Usaha Syariah, mencakup kelembagaan, kegiatan usaha serta cara dan proses dalam melaksanakan kegiatan usahanya. ${ }^{12}$ Kehadiran Bank Syariah dengan prinsip syariahnya yang tidak mengenal riba bagaikan angin segar bagi dunia perekonomian Indonesia terlebih Indonesia adalah negara yang mayoritas penduduknya beragama Islam tentunya keberadaan Bank Syariah sangat sesuai dengan kondisi tersebut. Bagi masyarakat yang beragama muslim pastinya tidak akan ragu dalam melakukan transaksi di Bank Syariah. Meskipun berdasarkan prinsip syariah, Bank Syariah tidak menutup diri terhadap masyarakat yang beragama non muslim. Hal ini dapat menunjukkan bahwa keberadaan Bank Syariah adalah untuk melayani seluruh warga Indonesia yang memerlukan tidak hanya terbatas pada kalangan tertentu saja. ${ }^{13}$

\section{Analisis Rasio Keuangan}

Analisis rasio keuangan sendiri dimulai dengan laporan keuangan dasar, yakni dari neraca (balance sheet), perhitungan rugi laba (income statement) dan laporan arus kas (cash flow statement). Perhitungan rasio keuangan akan lebih jelas kalau dihubungkan dengan menggunakan pola historis bank tersebut karena yang dilihat perhitungan pada sejumlah tahun untuk menentukan apakah bank membaik atau memburuk atau melakukan perbandingan dengan bank lain dalam industri yang sama. ${ }^{14}$

\section{Capital Adequacy Ratio (CAR)}

Rasio CAR merupakan bahagian dari modal yang dijadikan alat ukur kesanggupan bank membangun kepercayaan masyarakat, sehingga bank dapat menarik dana pihak ketiga (DPK). CAR juga memperlihatkan seberapa besar aktiva 
bank yang mengandung risiko, seperti pembiayaan, penyertaan, surat berharga dan tagihan pada bank lain dapat dibiayai dari modal sendiri di samping memperoleh

dana dari sumber-sumber di luar bank ${ }^{15}$ atau CAR adalah kecukupan modal yang menunjukkan kemampuan bank dalam memperhatikan modal yang mencukupi kemampuan manajemen bank dalam mengidentifikasi, mengukur, mengawasi dan mengontrol risiko-risiko yang timbul yang dapat berpengaruh terhadap besarnya modal bank. ${ }^{16}$

\section{Non Performing Financing (NPF)}

Dalam menjalankan bisnis perbankan yang penuh dengan risiko, Bank Syariah juga tidak terlepas dari risiko pembiayaan bermasalah, sehingga Bank Syariah perlu mengatur strategi agar tingkat NPF-nya tidak dalam kondisi yang mengkhawatirkan. ${ }^{17}$ Itulah sebabnya, Bank Syariah perlu tetap mengelola eksposur risiko pembiayaan pada tingkat yang memadai, sehingga dapat meminimalkan potensi kerugian dari penyediaan dana. Sebab, kodisi aset suatu perbankan masih tetap dipengaruhi oleh risiko pembiayaan yang jika tidak dikelola secara efektif, maka akan mengganggu kelangsungan usaha bank. ${ }^{18}$

\section{Financing to Deposit Ratio (FDR)}

FDR adalah rasio untuk mengukur likuiditas bank dari perbandingan antara pembiayaan yang diberikan dengan dana yang diterima. ${ }^{19}$ Rasio FDR ini juga dipergunakan untuk mengukur sampai sejauh mana dana pinjaman yang bersumber dari dana pihak ketiga. Tinggi rendahnya rasio ini menunjukkan tingkat likuiditas bank tersebut, sehingga jika semakin tinggi angka FDR suatu bank, maka berarti digambarkan sebagai bank yang kurang likuid dibanding dengan bank yang mempunyai angka rasio lebih kecil. ${ }^{20}$

\section{Biaya Operasional Terhadap Pendapatan Operasional (BOPO)}

Biaya operasional terhadap pendapatan operasional disebut BOPO adalah rasio yang digunakan untuk mengukur tingkat efisiensi dan kemampuan bank dalam melakukan kegiatan operasinya ${ }^{21}$ atau BOPO merupakan perbandingan atau rasio biaya operasional dalam 12 bulan terakhir terhadap pendapatan operasional dalam 
periode yang sama. ${ }^{22}$ Bank yang efisien dapat memberikan keuntungan dikarenakan biaya transaksi di perbankan tersebut lebih murah dibandingkan dengan perbankan lain yang tidak efisien. ${ }^{23}$

\section{Return On Asset (ROA)}

ROA adalah rasio yang menggambarkan kemampuan bank dalam mengelola

dana yang diinvestasikan dalam keseluruhan aset yang menghasilkan keuntungan ${ }^{24}$ atau ROA adalah salah satu rasio yang digunakan untuk mengukurkemampuan manajemen bank dalam memperoleh keuntungan (laba) secara keseluruhan. Rasio profitabilitas ini sekaligus menggambarkan efisiensi kinerja bank yang bersangkutan dikarenakan rasio ini mengutamakan nilai profitabilitas suatu bank yang diukur dengan aset produktif yang dananya sebagian besar berasal dari DPK. Jika semakin besar ROA suatu bank, maka semakin besar pula tingkat keuntungan yang dicapai bank tersebut dan semakin baik pula posisi bank tersebut dari segi penggunaan aset. $^{25}$

\section{Return On Equity (ROE)}

Return On Equity disebut ROE merupakan rasio profitabilitas yang membandingkan antar laba bersih (net profit) perusahaan dengan aset bersihnya (ekuitas atau modal). Rasio ini mengukur berapa banyak keuntungan yang dihasilkan

oleh perusahaan dibandingkan dengan modal yang disetor oleh pemegang saham ${ }^{26}$ yang memperlihatkan sejauh manakah perusahaan mengelola modal sendiri (net worth) secara efektif, mengukur tingkat keuntungan dari investasi yang telah dilakukan pemilik modal sendiri atau pemegang saham perusahaan. ${ }^{27}$

\section{Profitabilitas}

Profitabilitas bank adalah rasio yang digunakan untuk mengukur kemampuan bank dalam menghasilkan keuntungan (laba) dari aktivitas normal bisnisnya. ${ }^{28}$ Pengukuran rasio ini dapat dilakukan dengan membandingkan antara berbagai komponen yang ada di dalam laporan laba/rugi dan neraca. Faktor yang mempengaruhi profitabilitas di antaranya jumlah kecukupan modal, manajemen 
126 AT-TAWASSUTH: Jurnal Ekonomi Islam, Volume V No. 1

Januari - Juni 2020: 120 - 141

pengalokasian dana pada aktiva likuid dalam arti likuiditas serta efisiensi dalam menekan biaya operasi. ${ }^{29}$

\section{Metode Penelitian}

Metode penelitian pada dasarnya merupakan cara ilmiah untuk mendapatkan data dengan tujuan dan kegunaan tertentu. ${ }^{30}$ Populasi penelitian diperoleh dari Laporan Keuangan Bank Umum Syariah dan Unit Usaha Syariah yang dipublikasikan Direktorat Perbankan Syariah, Bank Indonesia serta Departemen Perizinan dan Informasi Perbankan, Otoritas Jasa Keuangan Republik Indonesia lewat Statistik Perbankan Syariah Bank Indonesia/Otoritas Jasa Keuangan (SPSBI/OJK) melalui situs resminya di www.bi.go.id. Dan www.ojk.go.id. Data sekundernya berupa data bulanan periode Januari 2006 hingga Januari 2018, sehingga diperoleh sampel sebanyak 145 data. Dalam penelitian ini, metode yang digunakan dengan pendekatan kuantitatif dengan teknik analisis regresi linier berganda yang dinyatakan dengan angka-angka dan perhitungannya menggunakan metode statistik yang dibantu dengan Program Statistical Product dan Service Solutions (SPSS). Analisis regresi berganda digunakan peneliti sekiranya peneliti bermaksud meramalkan bagaimana keadaan (naik turunnya) variabel terikat. Analisis regresi berganda pun dilakukan sekiranya jumlah variabel bebas minimal dua variabel. ${ }^{31}$

Model persamaan analisis regresi linier berganda dalam penelitian ini sebagai berikut:

$$
\mathrm{Y}=\mathrm{a}+\mathrm{b} 1 \mathrm{X} 1+\mathrm{b} 2 \mathrm{X} 2+\mathrm{b} 3 \mathrm{X} 3+\mathrm{b} 4 \mathrm{X} 4+\mathrm{b} 5 \mathrm{X} 5+\varepsilon .
$$

Keterangan:

$$
\begin{array}{ll}
\mathrm{Y} & =\text { Profitabilitas Bank Syariah di Indonesia } \\
\mathrm{a} & =\text { Konstanta(intercept) } \\
\mathrm{b} 1, \mathrm{~b} 2, \mathrm{~b} 3, \mathrm{~b} 4, \mathrm{~b} 5 & =\text { Koefisien regresi } \\
\varepsilon & =\text { Standar eror } \\
\mathrm{X} 1 & =\mathrm{CAR} \\
\mathrm{X} 2 & =\mathrm{NPF}
\end{array}
$$




$\begin{array}{ll}\mathrm{X} 3 & =\mathrm{BOPO} \\ \mathrm{X} 4 & =\mathrm{FDR} \\ \mathrm{X} 5 & =\mathrm{ROE}\end{array}$

\section{Analisis Data}

Analisis data adalah proses mencari dan menyusun secara sistematis data yang diperoleh dari hasil wawancara, catatan lapangan dan bahan-bahan lain, sehingga dapat mudah dipahami dan temuannya dapat diinformasikan kepada orang lain. ${ }^{32}$ Selanjutnya, tahapan analisis data penelitian diselesaikan dengan uji statistik:

1. Uji Ketepatan Letak Koefisien Determinasi R Square

Koefisien determinasi $\mathrm{R}$ Square $\left(\mathrm{R}^{2}\right)$ mengukur besarnya kemampuan semua variabel bebas dalam menjelaskan variasi dari variabel terikat. ${ }^{33}$

\section{Uji F (Uji Simultan)}

Suatu metode analisis statistik untuk menguji kesamaan atau lebih dari dua rata-rata populasi dinamakan analisis varians (ANOVA). Pengujian ini menggunakan distribusi $F$ dan pengujian dilakukan searah atas. ${ }^{34}$ Uji $F$ sering disebut dengan pengujian signifikansi keseluruhan terhadap garis regresi yang ingin menguji apakah Y (variabel terikat) secara linier berhubungan dengan variabel X (variabel bebas). Uji F bertujuan untuk mengidentifikasi apakah garis regresi dapat digunakan sebagai penaksir.

\section{Uji t (Uji Parsial)}

Uji t mengasumsikan berbagai variabel pada populasi dari mana sampel ditarik terdistribusi secara normal. Pengujian dengan uji t juga memiliki asumsi bahwa distribusi memiliki varians yang homogen yang bermakna penyimpangan setiap nilai atau skor adalah sama dari nilai rata-ratanya. Dengan demikian, penggunaan uji $t$ tergantung pada masalah dan situasi penelitian yang tengah dihadapi. Hasil uji $\mathrm{t}$ inilah hasil analisis regresi linier berganda. 
128 AT-TAWASSUTH: Jurnal Ekonomi Islam, Volume V No. 1

Januari - Juni 2020: 120 - 141

\section{Hasil Dan Pembahasan}

\section{Uji Koefisien Determinasi R Square}

Berdasarkan tabel 1, nilai R-nya sebesar 0,783 sebagai nilai korelasi berganda yang bermakna variabel bebas memiliki keeratan hubungan dengan variabel terikat. Sedangkan nilai R Square sebesar 0,614 yang mewakili nilai koefisien determinasi. Hal ini bermakna $61,40 \%$ dari variasi variabel ROA mampu dijelaskan oleh variabel bebas dalam model ini. Sedangkan sisanya sebesar 38,60\% dijelaskan oleh sebabsebab lain yang tidak masuk dalam model.

\section{Uji F (Uji Simultan)}

Analisis dan kesimpulan dari Tabel 1 adalah $\mathrm{H} 0$ tidak dapat diterima (ditolak) dan $\mathrm{Ha}$ dapat diterima (tidak dapat ditolak). Sebab, F hitung sebesar 44,130 lebih besar dari F tabel sebesar 2,28 dan nilai Sig. sebesar 0,000 yang lebih kecil dari 0,05. Hal ini bermakna model regresi pada variabel bebas secara simultan mempengaruhi variabel terikat, sehingga model regresi variabel bebas bisa dipakai untuk memprediksi variabel terikat.

\section{Uji t (Uji Parsial)}

Hasil uji t dilihat dari Tabel 1 ringkasan uji regresi sebagai berikut:

1. Variabel CAR mempunyai nilai t hitung sebesar 2,473 lebih besar dari t tabel sebesar 1,980 atau nilai Sig. sebesar 0,015 lebih kecil dari 0,05 yang berarti H0 tidak dapat diterima (ditolak) dan $\mathrm{H}_{\mathrm{a}}$ dapat diterima (tidak dapat ditolak). Dengan demikian, dapat ditarik kesimpulan bahwa variabel CAR berpengaruh positif dan signifikan terhadap variabel ROA.

2. Variabel NPF mempunyai nilai t hitung sebesar 5,765 lebih besar dari t tabel sebesar 1,980 atau nilai Sig. sebesar 0,000 lebih kecil dari 0,05 yang berarti H0 tidak dapat diterima (ditolak) dan $\mathrm{Ha}$ dapat diterima (tidak dapat ditolak). Dari arah hubungan, variabel NPF memiliki arah hubungan yang negatif terhadap variabel ROA. Dengan demikian, dapat ditarik kesimpulan bahwa variabel NPF berpengaruh negatif dan signifikan terhadap variabel ROA. 
Pani Akhiruddin: Risiko Keuangan Dan Pengaruhnya $\mid 129$

3. Variabel BOPO mempunyai nilai t hitung sebesar 1,475 lebih besar dari t tabel sebesar 1,980 atau nilai Sig. sebesar 0,143 lebih besar dari 0,05 yang berarti $\mathrm{H} 0$ dapat diterima (tidak dapat ditolak) dan Ha tidak dapat diterima (ditolak). Dari arah hubungan, variabel BOPO memiliki arah hubungan yang negatif terhadap variabel ROA. Dengan demikian, dapat ditarik kesimpulan bahwa variabel BOPO berpengaruh negatif dan tidak signifikan terhadap variabel ROA.

4. Variabel FDR mempunyai nilai t hitung sebesar 9,846 lebih besar dari t tabel 1,980 atau nilai Sig. sebesar 0,000 lebih kecil dari 0,05 yang berarti H0 tidak dapat diterima (ditolak) dan $\mathrm{Ha}$ dapat diterima (tidak dapat ditolak). Dengan demikian, dapat ditarik kesimpulan bahwa variabel FDR berpengaruh positif dan signifikan terhadap variabel ROA.

5. Variabel ROE mempunyai nilai t hitung sebesar 1,171 lebih kecil dari $t$ tabel 1,980 atau nilai Sig. sebesar 0,244 lebih besar dari 0,05 yang berarti $\mathrm{H} 0$ dapat diterima (tidak dapat ditolak) dan $\mathrm{Ha}$ tidak dapat diterima (ditolak). Dengan demikian, dapat ditarik kesimpulan bahwa variabel ROE berpengaruh positif dan tidak signifikan terhadap variabel ROA.

Tabel 1. Ringkasan Uji Regresi

\begin{tabular}{|c|c|c|c|}
\hline Model & $\mathrm{B}$ & $\mathrm{t}$ & $\mathrm{Si}$ \\
\hline Konstanta & $-1,937$ & $-2,901$ & 0,004 \\
\hline CAR & 0,015 & 2,473 & 0,015 \\
\hline NPF & $-0,199$ & $-5,765$ & 0,000 \\
\hline BOPO & $-0,007$ & $-1,475$ & 0,143 \\
\hline FDR & 0,046 & 9,846 & 0,000 \\
\hline ROE & 0,023 & 1,171 & 0,244 \\
\hline $\begin{array}{l}\mathrm{F}=44,130 \\
\mathrm{R}=0,783\end{array}$ & $\begin{array}{l}\text { Sig. }=0,000 \\
\mathrm{R}^{2}=0,614\end{array}$ & & \\
\hline
\end{tabular}

Sumber: Data penelitian yang diolah.

Dengan melihat tabel 1 ringkasan uji regresi, interpretasi dari persamaan regresi linier berganda ini adalah:

$$
\mathrm{ROA}=-1,937+0,015 \mathrm{CAR}-0,199 \mathrm{NPF}-0,007 \mathrm{BOPO}+0,046 \mathrm{FDR}+0,023 \mathrm{ROE}
$$

Interpretasi data sebagai berikut: 
130 AT-TAW ASSUTH: Jurnal Ekonomi Islam, Volume V No. 1

Januari - Juni 2020: 120 - 141

1. Konstanta 1,937 menunjukkan jika variabel CAR, variabel NPF, variabel BOPO, variabel FDR dan variabel ROE konstan, maka variabel ROA sebesar 1,937 bermakna ROA yang negatif disebabkan keuntungan (laba) Bank Syariah dalam merugi sebesar 1,937\%. Dengan kata lain, jika ROA semakin rendah, maka kinerja keuangan Bank Syariah semakin tidak baik. Hal ini menunjukkan kemampuan dari modal yang diinvestasikan Bank Syariah secara keseluruhan belum mampu untuk menghasilkan keuntungan. Oleh karenanya, dengan adanya faktor yang mempengaruhi ROA Bank Syariah tentunya memberikan pesan kepada pihak manajemen agar mampu menjaga indikator yang menyangkut kesehatan bank. Sebab, keberlanjutan Bank Syariah dalam kegiatan bisnisnya akan sangat dipengaruhi oleh besarnya keuntungan yang diperoleh.

2. Angka pada koefisien regresi variabel CAR sebesar 0,015 memberikan makna dengan meningkatnya kecukupan modal sebesar 1\% akan meningkatkan keuntungan sebesar 0,015\%. Dengan kecukupan modal yang tinggi, Bank Syariah dapat leluasa untuk menempatkan dananya ke dalam investasi yang menguntungkan dan kemungkinan berkembangnya Bank Syariah lebih baik. Hal ini menunjukkan bahwa aspek kecukupan modal Bank Syariah masih mencukupi untuk mendukung ekspansi bisnis Bank Syariah. Dengan demikian, jika CAR semakin tinggi, maka semakin baik kinerja Bank Syariah tersebut yang berdampak pada naiknya ROA Bank Syariah.

3. Angka pada koefisien regresi variabel NPF sebesar -0,199 memberikan makna semakin berkurangnya pembiayaan bermasalah (NPF) pada Bank Syariah sebesar $1 \%$ berpengaruh pada meningkatnya kesempatan Bank Syariah dalam memperoleh keuntungan dari pembiayaan yang diberikan sebesar 0,199\%. Pentingnya pembiayaan bagi Bank Syariah menjadikan Bank Syariah selalu mengembangkan pengelolaan pembiayaannya untuk dapat memaksimalkan keuntungan yang diterima termasuk menekan risiko terjadinya pembiayaan bermasalah. Jika NPF menurun atau dengan kata lain pembiayaan bermasalah semakin sedikit, maka permodalan Bank Syariah meningkat yang berdampak pada naiknya ROA Bank Syariah. 
Pani Akhiruddin: Risiko Keuangan Dan Pengaruhnya $\mid 131$

4. Angka pada koefisien regresi variabel BOPO sebesar -0,007 memberikan makna penurunan biaya operasional sebesar 1\% akan meningkatkan keuntungan sebelum pajak yang pada akhirnya menaikkan ROA Bank Syariah. Ini berarti setiap penurunan sebesar $0,007 \%$ rasio yang mengukur efisiensi dan efektivitas operasional Bank Syariah dalam mengendalikan biaya operasional terhadap pendapatan operasional mengakibatkan semakin efisiennya biaya operasional yang dikeluarkan Bank Syariah. Oleh karenanya, jika BOPO nilainya semakin kecil, maka semakin efisien Bank Syariah menjalankan kegiatannya dalam penggunaan sumber daya, sehingga BOPO yang menurun berdampak pada naiknya ROA Bank Syariah.

5. Angka pada koefisien regresi variabel FDR sebesar 0,046 memberikan makna FDR memberikan pengaruh positif terhadap ROA sebesar 1\%. Sebab, semakin besarnya pembiayaan tentunya pendapatan yang diperoleh Bank Syariah naik. Dengan naiknya pendapatan, keuntungan juga akan mengalami kenaikan, sehingga dari bermacam-macam pembiayaan diharapkan dapat meningkatkan ROA Bank Syariah sebesar 0,046\%. Jika rasio FDR semakin tinggi, maka semakin tinggi dana yang disalurkan ke DPK, sehingga FDR yang meningkat berdampak pada naiknya ROA Bank Syariah.

6. Angka pada koefisien regresi variabel ROE sebesar 0,023 memberikan makna tingkat pengembalian dana yang diinvestasikan semakin tinggi sebesar 1\% karena investor menganggap perusahaan mempunyai prospek yang baik dalam meningkatkan ROA sebesar 0,023\%. Jika rasio ROE semakin tinggi, maka semakin efisien dan efektif pengelolaan modal pemegang saham dan menunjukkan tingkat profitabilitas yang tinggi. Oleh karenanya, tingkat ROE yang tinggi akan membawa keberhasilan yang berdampak pada naiknya ROA Bank Syariah.

\section{Pengaruh Variabel CAR Terhadap Variabel ROA}

Berdasarkan angka pada koefisien regresi, angka koefisien regresi variabel CAR sebesar 0,015 dan nilai Sig. sebesar 0,015 lebih kecil dari 0,05 memberikan makna adanya hubungan yang searah dan signifikan antara variabel CAR dengan 
132 AT-TAW ASSUTH: Jurnal Ekonomi Islam, Volume V No. 1

Januari - Juni 2020: 120 - 141

variabel ROA. Hasil penelitian ini sesuai dengan teori yang menyatakan CAR berpengaruh positif dan signifikan terhadap ROA.

Variabel CAR, yakni rasio kecukupan modal dimaksudkan untuk menutupi potensi kerugian yang tidak terduga (unexpected loss) dan sebagai cadangan pada saat terjadi krisis perbankan. CAR didasarkan pada prinsip bahwa setiap penanaman yang mengandung risiko harus disediakan jumlah modal sebesar persentase tertentu terhadap jumlah penanamannya karena tingginya rasio kecukupan modal dapat melindungi deposan dan naiknya tingkat kepercayaan nasabah kepada Bank Syariah. Oleh karenanya, naiknya rasio kecukupan modal sebesar 1\% berdampak pada meningkatnya ROA Bank Syariah sebesar 0,015\%. Jika CAR naik, maka ROA naik. Manajemen Bank Syariah perlu mempertahankan dan meningkatkan nilai CAR sesuai dengan ketentuan Bank Indonesia karena dengan modal yang cukup, Bank Syariah mampu melakukan ekspansi usaha dengan lebih aman dalam rangka meningkatkan ROA. Oleh Bank Indonesia, CAR disyaratkan minimal 8\%.

Bank Syariah yang memiliki tingkat kecukupan modal yang tinggi akan mampu memperoleh profit yang tinggi dibandingkan dengan Bank Syariah yang yang memiliki tingkat kecukupan modal yang rendah. CAR merupakan indikator terhadap kemampuan bank untuk menutupi penurunan aktivanya sebagai akibat dari kerugian-kerugian bank yang disebabkan oleh aktiva yang berisiko yang pada akhirnya meningkatkan pendapatan Bank Syariah. Nasabah tentunya akan mempercayakan dananya untuk ditempatkan di Bank Syariah yang teruji memiliki kecukupan modal yang tinggi. Penetapan CAR pada titik tertentu juga dimaksudkan agar Bank Syariah memiliki kecukupan modal yang cukup untuk meredam kemungkinan timbulnya risiko sebagai akibat berkembangnya ekspansi aset terutama aktiva yang dikategorikan dapat memberikan hasil sekaligus mengandung risiko. Rasio CAR juga memperlihatkan seberapa jauh seluruh aktiva bank yang mengandung risiko (pembiayaan, penyertaan, surat berharga, tagihan pada bank lain) ikut dibiayai dari dana modal sendiri bank di samping memperoleh dana-dana dari sumber lain di luar bank, seperti dana masyarakat, pinjaman (hutang) dan lain-lain dengan catatan sesuai ceteris paribus. 
Pani Akhiruddin: Risiko Keuangan Dan Pengaruhnya $\mid 133$

\section{Pengaruh Variabel NPF Terhadap Variabel ROA}

Berdasarkan angka pada koefisien regresi, angka koefisien regresi variabel NPF sebesar -0,199 dan nilai Sig. sebesar 0,000 lebih kecil dari 0,05 memberikan makna adanya hubungan yang searah dan signifikan antara variabel NPF dengan variabel ROA. Hasil penelitian ini sesuai dengan teori yang menyatakan NPF berpengaruh negatif dan signifikan terhadap ROA.

Variabel NPF, yakni mencerminkan rasio pembiayaan bermasalah yang terjadi ketika nasabah karena berbagai sebab serta alasan tidak dapat memenuhi kewajibannya untuk mengembalikan dana pembiayaan (pinjaman) yang telah diberikan Bank Syariah. Jika semakin rendah NPF, maka menunjukkan kualitas pembiayaan Bank Syariah semakin baik ataupun jika NPF berkurang sebesar 1\% maka berpengaruh pada meningkatnya kesempatan Bank Syariah untuk memperoleh keuntungan dari pembiayaan yang diberikan berdampak pada meningkatnya ROA Bank Syariah sebesar 0,199\% yang menunjukkan kualitas pembiayaan Bank Syariah semakin baik. Sebab, jika NPF turun, maka ROA naik. Sebaliknya, jika semakin tinggi rasio NPF, maka menunjukkan kualitas pembiayaan Bank Syariah semakin buruk. Oleh karenanya, besarnya persentase NPF haruslah menjadi perhatian pihak manajemen karena dapat mempengaruhi keuntungan usaha Bank Syariah. Oleh Bank Indonesia, NPF disyaratkan minimal 5\%.

Pembiayaan bermasalah adalah pembiayaan dengan kualitas kurang lancar $(\mathrm{KL})$, diragukan (D) dan macet (M). Oleh karena itu, risiko pembiayaan yang diterima Bank Syariah merupakan risiko yang disebabkan karena adanya ketidakpastian pengambilan atau tidak dilunasinya kembali pembiayaan yang diberikan Bank Syariah ke nasabah. Risiko pembiayaan pun dapat meningkat sekiranya Bank Syariah meminjamkan kepada nasabah yang tidak memiliki pengetahuan yang memadai. Pentingnya pembiayaan bagi Bank Syariah menjadikan Bank Syariah selalu mengembangkan pengelolaan pembiayaannya untuk dapat memaksimalkan keuntungan yang diterima dan termasuk pula menekan risiko terjadinya pembiayaan bermasalah. Dengan demikian, Bank Syariah dapat meminimalisir risiko pembiayaan yang dialami akibat kegagalan atau 
134 AT-TAWASSUTH: Jurnal Ekonomi Islam, Volume V No. 1

Januari - Juni 2020: 120 - 141

ketidakmampuan nasabah dalam pengembalian jumlah pinjaman yang diterima dari Bank Syariah beserta bagi hasilnya sesuai dengan jangka waktu yang telah dijadwalkan. Hal ini menandakan Bank Syariah mampu meningkatkan dan menghasilkan keuntungan dengan catatan sesuai ceteris paribus.

\section{Pengaruh Variabel BOPO Terhadap Variabel ROA}

Berdasarkan angka pada koefisien regresi, angka koefisien regresi variabel BOPO sebesar -0,007 dan nilai Sig. sebesar 0,143 lebih besar dari 0,05 memberikan makna adanya hubungan yang searah dan tidak signifikan antara variabel BOPO dengan variabel ROA. Hasil penelitian ini tidak sesuai dengan teori yang menyatakan BOPO berpengaruh negatif dan signifikan terhadap ROA.

Variabel BOPO, yakni menunjukkan rasio seberapa besar bank dapat menekan biaya operasionalnya di satu pihak dan seberapa besar kemampuan bank untuk meningkatkan pendapatan operasionalnya di lain pihak. Rasio BOPO bertujuan untuk mengukur kemampuan pendapatan operasional dalam menutup biaya operasional. Manfaat masyarakat maupun nasabah mengetahui rasio BOPO adalah agar masyarakat tahu seberapa efisien Bank Syariah dalam mengendalikan biaya operasionalnya dan masyarakat semakin percaya dengan Bank Syariah. Jika Bank Syariah semakin efisien yang berarti rasio BOPO semakin kecil sebesar 1\%, maka ROA yang diperoleh Bank Syariah semakin besar sebesar 0,007\%. Jika BOPO turun, maka ROA naik. Oleh Bank Indonesia, BOPO disyaratkan minimal 85\%.

Itulah mengapa, jumlah biaya operasional yang besar akan memperkecil jumlah keuntungan (laba) yang akan diperoleh karena biaya atau beban operasional bertindak sebagai faktor pengurang dalam laporan laba rugi. Dengan adanya efisiensi pada Bank Syariah terutama efisiensi biaya, tentunya akan diperoleh tingkat keuntungan yang optimal, penambahan jumlah dana yang disalurkan, biaya lebih kompetitif, peningkatan pelayanan kepada nasabah, keamanan dan kesehatan Bank Syariah yang meningkat. Biaya operasional dan pendapatan operasional dijadikan variabel bebas yang mempengaruhi ROA didasarkan hubungannya dengan tingkat risiko Bank Syariah yang bermuara pada ROA Bank Syariah. BOPO telah menjadi salah satu rasio yang perubahan

nilainya sangat diperhatikan terutama bagi sektor perbankan mengingat salah satu kriteria 
Pani Akhiruddin: Risiko Keuangan Dan Pengaruhnya $\mid 135$

penentuan tingkat kesehatan bank oleh Bank Indonesia adalah besaran rasio ini. Lalu, mengingat kegiatan utama perbankan pada prinsipnya adalah bertindak sebagai perantara, yakni menghimpun dan menyalurkan dana masyarakat. Jadinya, biaya dan pendapatan operasional bank didominasi oleh biaya margin dan bagi hasil. BOPO disebut juga merupakan rasio biaya operasional dalam 12 bulan terakhir terhadap pendapatan operasional dalam periode yang sama dengan catatan sesuai ceteris paribus.

\section{Pengaruh Variabel FDR Terhadap Variabel ROA}

Berdasarkan angka pada koefisien regresi, angka koefisien regresi variabel FDR sebesar 0,046 dan nilai Sig. sebesar 0,000 lebih kecil dari 0,05 memberikan makna adanya hubungan yang searah dan signifikan antara variabel FDR dengan variabel ROA. Hasil penelitian ini sesuai dengan teori yang menyatakan FDR berpengaruh positif dan signifikan terhadap ROA.

Variabel FDR, yakni rasio perbandingan antara pembiayaan yang diberikan oleh bank dengan DPK dimaksudkan untuk mengukur sejauh mana dana pinjaman yang bersumber dari DPK. FDR tersebut menyatakan besaran kemampuan Bank Syariah dalam membayar kembali penarikan dana yang dilakukan deposan dengan mengandalkan pembiayaan yang diberikan sebagai sumber likuiditasnya. FDR juga merupakan indikator untuk mengetahui kerawanan suatu bank dalam menilai faktor likuiditas. Sulitnya pengelolaan likuiditas disebabkan dana yang dikelola bank sebagian besar adalah dana masyarakat yang bersifat jangka pendek dan dapat ditarik sewaktuwaktu. Jika semakin tinggi rasio FDR sebesar 1\%, maka semakin tinggi dana yang disalurkan ke DPK, sehingga FDR yang meningkat dapat meningkatkan ROA Bank Syariah sebesar 0,046\%. Jika FDR naik, maka ROA ikut naik. Rasio FDR yang besar tentunya dana yang disalurkan ke DPK juga besar. Dengan penyaluran DPK yang besar, tentunya pendapatan Bank Syariah terhadap ROA meningkat berdampak FDR berpengaruh positif terhadap ROA. Oleh Bank Indonesia, FDR disyaratkan minimal $85 \%$.

Pengelolaan likuiditas yang baik dapat menunjang kesehatan dan kestabilan perbankan dan mengurangi risiko kebangkrutan Bank Syariah. Di saat Bank Syariah memegang aset berupa kas yang besar, kesempatan untuk memberikan pembiayaan 
136 AT-TAWASSUTH: Jurnal Ekonomi Islam, Volume V No. 1

Januari - Juni 2020: 120 - 141

dalam rangka memaksimalkan pendapatan menjadi terbatas. Sebaliknya, jika semua dana disalurkan untuk pembiayaan, maka Bank Syariah dapat menghasilkan profit yang besar. Namun, dampaknya likuiditas menjadi rendah, sehingga Bank Syariah menghadapi risiko likuiditas yang tinggi. Bagaimana mengelola likuiditas menjadi aspek penting yang harus diperhatikan untuk menjaga kelangsungan hidup Bank Syariah sangat mutlak diperlukan. Jika ingin mempertahankan posisi likuiditas dengan memperbesar cadangan kas, maka seharusnya Bank Syariah tidak akan memakai seluruh loan-able funds yang ada karena sebagian dikembalikan lagi dalam bentuk cadangan tunai (cash reserve). Hal ini berarti usaha pencapaian ROA akan berkurang. Sebaliknya, jika Bank Syariah ingin mempertinggi ROA, maka dengan cash reserve untuk likuiditas terpakai oleh bisnis Bank Syariah, sehingga posisi likuiditas akan turun. Jika rasio ini meningkat dalam batas tertentu, maka akan semakin banyak dana yang disalurkan dalam bentuk pembiayaan dengan catatan sesuai ceteris paribus.

\section{Pengaruh Variabel ROE Terhadap Variabel ROA}

Berdasarkan angka pada koefisien regresi, angka koefisien regresi variabel ROE sebesar 0,023 dan nilai Sig. sebesar 0,244 lebih besar dari 0,05 memberikan makna adanya hubungan yang searah dan tidak signifikan antara variabel ROE dengan variabel ROA. Hasil penelitian ini tidak sesuai dengan teori yang menyatakan ROE berpengaruh positif dan signifikan terhadap ROA.

Variabel ROE, yakni rasio untuk mengukur kemampuan manajemen perbankan syariah dalam pengelolaan modal yang ada untuk mendapatkan pendapatan laba bersih sebelum pajak. Rasio ini menunjukkan kemampuan perusahaan dalam menghasilkan laba setelah dikurangi beban termasuk pajak dengan menggunakan modal sendiri yang dimiliki perusahaan. Sebab, rasio ROE bertujuan untuk mengetahui efisiensi manajemen dalam menjalankan modalnya dan akhirnya kepercayaan investor atas modal yang diinvestasikannya terhadap perusahaan sebesar 1\% lebih baik serta dapat memberi pengaruh positif bagi harga sahamnya di pasar dan meningkatnya ROA perusahaan terlebih Bank Syariah sebesar 0,023\%. Jika semakin tinggi rasio ROE, maka semakin efisien dan efektif pengelolaan modal pemegang saham dan menunjukkan tingkat profitabilitas yang tinggi. Oleh Bank Indonesia, ROE disyaratkan minimal 5\%. 
Tingkat ROE yang tinggi akan membawa keberhasilan bagi perusahaan. Perusahaan yang menggunakan hutang untuk membiayai sebagian aset perusahaan akan memiliki ROE yang lebih tinggi daripada perusahaan yang hanya menggunakan modal investor saat kondisi usaha perusahaan baik. Sebab, perusahaan akan mengalami risiko kerugian atau memiliki ROE yang lebih kecil daripada perusahaan yang hanya menggunakan modal investor saat kondisi usaha perusahaan memasuki masa sulit. Hal ini berarti sebaiknya perusahaan membandingkan antara perkiraan ROE yang lebih tinggi dengan meningkatnya risiko dalam mengambil keputusan digunakannya hutang. Kemudian, adanya pertumbuhan ROE menunjukkan prospek perusahaan yang semakin baik yang berarti adanya potensial peningkatan keuntungan yang diperoleh perusahaan, sehingga akan meningkatkan kepercayaan investor serta akan mempermudah manajemen perusahaan untuk menarik modal dalam bentuk saham. Dengan demikian, ROE ini menghubungkan laba bersih yang diperoleh dari operasi perusahaan dengan jumlah modal sendiri yang dimiliki. Bagi pihak investor, ROE digunakan untuk melihat dan meramalkan apakah perusahaan tersebut layak menerima investasi dan untuk mengantisipasi adanya hal yang tidak diinginkan di masa yang akan datang.

\section{Kesimpulan}

Berdasarkan penelitian yang telah dilakukan didapatkan hasil bahwa model estimasi menunjukkan nilai $\mathrm{R}$ Square-nya sebesar 0,614 yang mewakili nilai koefisien determinasi. Hal ini bermakna $61,40 \%$ dari variasi variabel ROA mampu dijelaskan oleh variabel bebas dalam model ini. Sedangkan sisanya sebesar $38,60 \%$ dijelaskan oleh sebab- sebab lain yang tidak masuk dalam model. Model regresi pada variabel bebas secara simultan mempengaruhi variabel terikat, sehingga model regresi variabel bebas bisa dipakai untuk memprediksi variabel terikat. CAR, NPF dan FDR memiliki hubungan yang searah dan signifikan dengan ROA. BOPO dan ROE pun memiliki hubungan yang searah dengan ROA. Akan tetapi, tidak signifikan.

\footnotetext{
(Endnote)

1 Undang-Undang Nomor 10 Tahun 1998 Tentang Perbankan tanggal 10 Nopember 1998 Tentang Perubahan Atas Undang-Undang Nomor 7 tanggal 25 Maret 1992.

${ }^{2}$ Imam Wahyudi et al., Manajemen Risiko Bank Islam (Jakarta: Salemba Empat, 2013), h. 31.
} 
${ }^{3}$ Rachmat Firdaus, Manajemen Dana Bank (Bandung: STIE INABA, 2001), h. 29.

${ }^{4}$ Kasmir, Analisis Laporan Keuangan (Jakarta: PT. Rajagrafindo Persada, 2010), h. 104.

${ }^{5}$ Karen A. Horcher, Essentials of Financial Risk Management (New Jersey: John Wiley \& Sons, Inc., 2005), h. 1.

${ }^{6}$ Peraturan Bank Indonesia Nomor 9/1/PBI/2007 Tentang Sistem Penilaian Tingkat Kesehatan Bank Umum Berdasarkan Prinsip Syariah tanggal 24 Januari 2007.

${ }_{7}^{7}$ Peraturan Bank Indonesia Nomor 13/23/PBI/2011 Tentang Penerapan Manajemen Risiko Bagi Bank Umum Syariah dan Unit Usaha Syariah tanggal 02 Nopember 2011.

${ }^{8}$ Veithzal Rivai dan Arviyan Arifin, Islamic Banking: Sebuah Teori, Konsep dan Aplikasi (Jakarta: Bumi Aksara, 2010), h. 941.

9 Robert Tampubolon, Manajemen Risiko Pendekatan Kualitatif Untuk Bank Komersial (Jakarta: Elex Media Komputindo, 2004), h. 41.

${ }^{10}$ Hasanuddin Rahman, Aspek-Aspek Hukum Pemberian Kredit Perbankan di Indonesia (Bandung: Citra Aditya Bakti, 1995), h.16.

${ }^{11}$ Lukman Dendawijaya, Manajemen Perbankan (Jakarta: Ghalia Indonesia, 2009), h. 118.

${ }^{12}$ Undang-Undang Nomor 21 Tahun 2008 Tentang Perbankan Syariah tanggal 16 Juli 2008.

13 Abdul Ghofur Anshori, Perbankan Syariah di Indonesia (Yogyakarta: Gajah Mada University Press, 2007), h, 98.

${ }^{14}$ Irham Fahmi, Pengantar Manajemen Keuangan: Teori dan Soal Jawab (Bandung: CV. Alfabeta, 2016), h. 50.

${ }^{15}$ Farah Margaretha, Manajemen Keuangan Bagi Industri Jasa (Jakarta: Grasindo, 2007), h. 63.

${ }^{16}$ Mudrajad Kuncoro dan Suhardjono, Manajemen Perbankan Teori dan Aplikasi (Yogyakarta: BPFE Yogyakarta, 2011), h. 519.

${ }^{17}$ Muhammad Syafi'i Antonio, Bank Syariah: Dari Teori ke Praktik (Jakarta: Gema Insani, 2001), h. 107.

${ }^{18}$ Iswi Hariyani, Kredit Macet (Jakarta: PT. Gramedia Pustaka Utama, 2010), h. 5.

${ }^{19}$ Taswan, Manajemen Perbankan (Yogyakarta: UPP STIM YKPN, 2010), h. 245.

${ }^{20}$ Muhammad, Manajemen Pembiayaan Bank Syariah (Yogyakarta: UPP AMP YKPN, 2005), h.

55.

21 Veithzal Rivai, Credit Management Handbook Manajemen Perkreditan Cara-Cara Mudah Menganalisis Kredit (Jakarta: PT. Rajagrafindo Persada, 2013), h. 131.

${ }_{22}$ Malayu Hasibuan, Manajemen Sumber Daya Manusia (Jakarta: Bumi Aksara, 2011), h. 101.

${ }^{23}$ Rahmad Hidayat, Efisiensi Perbankan Syariah (Bekasi: Gramata Publishing, 2014), h. 64.

24 Dwi Suwiknyo, Analisis Laporan Keuangan Perbankan Syariah (Yogyakara: Pustaka Pelajar, 2016), h. 149

${ }^{25}$ Slamet Riyadi, Banking Assets and Liability Management (Jakarta: LPFE-UI, 2006), h. 155-156.

26 Agus Sartono, Manajemen Keuangan: Teori dan Aplikasi, (BPFE Yogyakarta, Yogyakarta, 2001), h. 122.

27 Agnes Sawir, Analisa Kinerja Keuangan dan Perencanaan Keuangan Perusahaan, PT. Gramedia Pustaka Utama, Jakarta, 2009, h. 20.

${ }^{28}$ Hery, Analisis Laporan Keuangan: Pendekatan Rasio Keuangan (Jakarta: CAPS Publishing, 2015), h. 226.

${ }^{29}$ Mahmoedin, Melacak Kredit Bermasalah (Jakarta: Pustaka Sinar Harapan, 2004), h. 202.

${ }^{30}$ Etta Mamang Sangadji dan Sopiah, Metodologi Penelitian: Pendekatan Praktis Dalam Penelitian (Yogyakarta: ANDI, 2010), h. 4.

31 Sugiyono dan Agus Susanto, Cara Mudah Belajar SPSS \& Lisrel, Teori dan Aplikasi Untuk Analisis Data Penelitian (Bandung: CV. Alfabeta, 2015), h. 303.

32 Sugiyono, Metode Penelitian Kuantitatif, Kualitatif dan R \& D (Bandung: CV. Alfabeta, 2013), h, 244.

${ }^{33}$ Imam Ghozali, Aplikasi Analisis Multivariate Dengan Program SPSS 21: Update PLS Regresi (Semarang: Universitas Diponegoro, 2013), h. 244.

${ }^{34}$ Sri Mulyono, Statistika Untuk Ekonomi \& Bisnis (Jakarta: Mitra Wacana Media, 2017), h. 186. 
Pani Akhiruddin: Risiko Keuangan Dan Pengaruhnya 139

\section{DAFTAR PUSTAKA}

Anshori, Abdul Ghofur. 2007. Perbankan Syariah di Indonesia. Yogyakarta: Gajah Mada University Press.

Antonio, Muhammad Syafi'i. 2001. Bank Syariah: Dari Teori ke Praktik. Jakarta: Gema Insani.

Dendawijaya, Lukman. 2009. Manajemen Perbankan. Jakarta: Ghalia Indonesia.

Fahmi, Irham. 2016. Pengantar Manajemen Keuangan: Teori dan Soal Jawab. Bandung: CV. Alfabeta.

Firdaus, Rachmat. 2001. Manajemen Dana Bank. Bandung: STIE INABA.

Ghozali, Imam. 2013. Aplikasi Analisis Multivariate Dengan Program SPSS 21: Update PLS Regresi. Semarang: Universitas Diponegoro.

Hariyani, Iswi. 2010. Kredit Macet. Jakarta: PT. Gramedia Pustaka Utama.

Hasibuan, Malayu. 2011. Manajemen Sumber Daya Manusia. Jakarta: Bumi Aksara.

Hery. 2015. Analisis Laporan Keuangan: Pendekatan Rasio Keuangan. Jakarta: CAPS Publishing.

Hidayat, Rahmad. 2014. Efisiensi Perbankan Syariah. Bekasi: Gramata Publishing.

Horcher, Karen A. 2005. Essentials of Financial Risk Management. New Jersey: John Wiley \& Sons, Inc.

Kasmir. Analisis Laporan Keuangan. 2010. Jakarta: PT. Rajagrafindo Persada.

Kuncoro, Mudrajad dan Suhardjono. 2011. Manajemen Perbankan Teori dan Aplikasi. Yogyakarta: BPFE Yogyakarta. 
140 AT-TAWASSUTH: Jurnal Ekonomi Islam, Volume V No. 1 Januari - Juni 2020: 120 - 141

Mahmoedin. 2004. Melacak Kredit Bermasalah. Jakarta: Pustaka Sinar Harapan.

Margaretha, Farah. 2007. Manajemen Keuangan Bagi Industri Jasa. Jakarta: Grasindo.

Muhammad. 2004. Manajemen Dana Bank Syariah. Yogyakarta: Ekonisia.

Mulyono, Sri. 2017. Statistika Untuk Ekonomi \& Bisnis. Jakarta: Mitra Wacana Media.

Peraturan Bank Indonesia Nomor 13/23/PBI/2011 Tentang Penerapan Manajemen Risiko Bagi Bank Umum Syariah dan Unit Usaha Syariah tanggal 02 Nopember 2011.

Peraturan Bank Indonesia Nomor 9/1/PBI/2007 Tentang Sistem Penilaian Tingkat Kesehatan Bank Umum Berdasarkan Prinsip Syariah tanggal 24 Januari 2007.

Rahman, Hasanuddin. 1995. Aspek-Aspek Hukum Pemberian Kredit Perbankan di Indonesia. Bandung: Citra Aditya Bakti.

Rivai, Veithzal dan Arifin, Arviyan. 2010. Islamic Banking: Sebuah Teori, Konsep dan Aplikasi. Jakarta: Bumi Aksara.

Rivai, Veithzal. 2013. Credit Management Handbook Manajemen Perkreditan CaraCara Mudah Menganalisis Kredit. Jakarta: PT. Rajagrafindo Persada.

Riyadi, Slamet. 2006. Banking Assets and Liability Management. Jakarta: LPFE-UI.

Sangadji, Etta Mamang dan Sopiah. 2010. Metodologi Penelitian: Pendekatan PraktisDalam Penelitian. Yogyakarta: ANDI.

Sartono, Agus. 2001. Manajemen Keuangan: Teori dan Aplikasi. Yogyakarta: BPFE Yogyakarta. 
Pani Akhiruddin: Risiko Keuangan Dan Pengaruhnya $\mid 141$

Sawir, Agnes. 2009. Analisa Kinerja Keuangan dan Perencanaan Keuangan Perusahaan. Jakarta: PT. Gramedia Pustaka Utama.

Sugiyono dan Susanto, Agus. 2015. Cara Mudah Belajar SPSS \& Lisrel, Teori dan Aplikasi Untuk Analisis Data Penelitian. Bandung: CV. Alfabeta.

Sugiyono. 2013. Metode Penelitian Kuantitatif, Kualitatif dan $R \& D$. Bandung: CV. Alfabeta.

Suwiknyo, Dwi. 2016. Analisis Laporan Keuangan Perbankan Syariah. Yogyakara: Pustaka Pelajar.

Tampubolon, Robert. 2004. Manajemen Risiko Pendekatan Kualitatif Untuk Bank Komersial. Jakarta: Elex Media Komputindo.

Taswan. 2010. Manajemen Perbankan. Yogyakarta: UPP STIM YKPN.

Undang-Undang Nomor 10 Tahun 1998 Tentang Perbankan tanggal 10 Nopember 1998 Tentang Perubahan Atas Undang- Undang Nomor 7 tanggal 25 Maret 1992.

Undang-Undang Nomor 21 Tahun 2008 Tentang Perbankan Syariah tanggal 16 Juli 2008.

Wahyudi, Imam et al. 2013. Manajemen Risiko Bank Islam. Jakarta: Salemba Empat. 